\title{
Bacteria from the Bacillus cereus group as contaminants in requeijão curd cheeses and especialidade láctea tipo requeijão
}

\section{Bactérias do grupo Bacillus cereus como contaminantes em queijos fundidos requeijão e especialidade láctea tipo requeijão}

\author{
Jamile de Oliveira Hachiya ${ }^{1}$, Gabriel Augusto Marques Rossi ${ }^{1 *}$, Higor Oliveira Silva1, \\ Rafael Akira Sato', Ana Maria Centola Vidal'2, Luiz Augusto do Amaral'
}

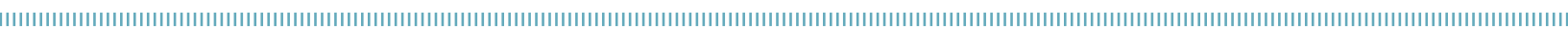

\begin{abstract}
This study aimed to evaluate the occurrence of Bacillus cereus group in requeijöes and especialidades lácteas tipo requeijáo (regular and light) and to verify if there is differences in relation to this occurrence among different categories of these products. A set of $14(35 \%)$ lots was contaminated with this bacterial group from the 40 lots with low counts (maximum $3.1 \times 10 \mathrm{CFU} / \mathrm{g}$ ), and no significant difference regarding counts or presence/absence were observed among the categories of the products. It can be concluded that contamination by $B$. cereus group in these products is unable to consist in risk to consumers, regarding adequate refrigeration during selling. This study was the first one to report this bacteria group for these dairy products and highlights the needs of further investigations to evaluate the impact of its spoilage during shelf life.
\end{abstract}

KEYWORDS: spores, dairy; milk; microbiology; food safety.
RESUMO: Este estudo objetivou avaliar a ocorrência de bactérias do grupo de Bacillus cereus em requeijōes e especialidades lácteas (normais e light) e verificar se há diferença em relação a essa ocorrência entre as diferentes categorias desses produtos. Entre os 40 lotes avaliados, 14 (35\%) estavam contaminados por bactérias desse grupo, com baixas contagens (máxima de 3,1 × $10 \mathrm{UFC/g}$ ) e sem diferenças significativas no que tange às contagens ou à presença/ausência entre as diversas categorias. Conclui-se que as bactérias do grupo de $B$. cereus em requeijōes e especialidades lácteas são incapazes de consistir em risco aos consumidores desses produtos, desde que as condiçôes de refrigeração sejam adequadas durante armazenamento e venda. O presente trabalho é o primeiro a relatar a presença de tal grupo de micro-organismos nesses tipos de produtos, porém, são necessários novos estudos para avaliar o impacto de sua açáo deteriorante sobre o período em que passa na prateleira.

PALAVRAS-CHAVE: alimentos, laticínios; leite, microbiologia; segurança alimentar.

'Universidade Estadual Paulista “Júlio de Mesquita Filho”, Faculdade de Ciências Agrárias e Veterinárias - Jaboticabal (SP), Brazil ${ }^{2}$ Universidade de São Paulo, Faculdade de Zootecnia e Engenharia de Alimentos - Pirassununga (SP), Brazil

*Corresponding author: gabrielrossiveterinario@hotmail.com 
The Bacillus cereus group is composed of eight species, including B. cereus sensu stricto (s. s.), Bacillus thuringiensis, Bacillus mycoides, Bacillus pseudomycoides, Bacillus anthracis, Bacillus weihenstephanensis, Bacillus cytotoxicus (GUINEBRETIÉRE et al., 2013) and Bacillus toyonensis (JIMÉNEZ et al., 2013). The bacteria belonging to this group are rod-shaped, gram-positive, facultatively anaerobe, spore-producers (allowing their survival to heat-treatment) and widespread on environment (FDA, 2012).

These bacteria are genomically similar besides their phonotypical differences, such as the ability to cause foodborne illness and anthrax, or to be used on biological pest control. The genetic differentiation on these species is possible. However, it still presents some difficulties due the high genetic similarity among these species and plasmids transfer (KOVAC et al., 2016).

The species $B$. cereus s. s. is highlighted in this group due its importance on food production chain considering its ability to cause emetic and diarrheal syndrome (FDA, 2012) and foodborne outbreaks (ZHOU et al., 2014). Yet, other species are also considered able to cause foodborne illness (GUINEBRETIÉRE et al., 2013). The dairy products are not often involved in these outbreaks (BENNET et al., 2013), but this group is important to dairy industries due its ability to form biofilms and result in food spoilage (KUMARI; SARKAR, 2016).

This group is reported as contaminant in several dairy products (KUMARI; SARKAR, 2016), but there are no studies published on literature reporting its presence on requeijão curd cheeses and especialidade láctea tipo requeijäo, which are highly consumed in Brazil (ZACARCHENCO et al., 2012). Requeijāo curd cheese is produced using acid coagulation of milk followed by a mass fusion $\left(80^{\circ} \mathrm{C}\right.$ during 5 seconds), whey removal and washing, and the addition of fat milk is allowed (BRAZIL, 1997). Furthermore, a very similar dairy product (especialidade láctea tipo requeijäo) is often consumed in Brazil, differing from the first product cited by the addition of cornstarch.

Thus, this study aimed to counting bacteria belonging to B. cereus group in requeijão curd cheeses and especialidade láctea tipo requeijāo (regular and light) marketed in the state of São Paulo, Brazil, and verify if there is difference in relation to this occurrence among these categories. For this purpose, 200 samples of requeijão and especialidade láctea tipo requeijäo were bought on supermarkets located in Jaboticabal, São Paulo, in 2015.

The samples were processed in groups of five unities each (one lot), as it follows:

1. 50 samples of requeijäo normal', from five commercial brands and ten production lots;

2. 50 samples of requeijäo light", from five brands and ten lots;

3. 50 samples of especialidade láctea, from five brands and ten lots;

4. 50 samples of especialidade láctea light, from three brands and ten production lots (Table 1).
The asepsis of package was performed using ethanol $10 \%$, and posteriorly $25 \mathrm{~g}$ of the samples were transferred to flasks containing sterile peptone water $0.1 \%$ to obtain the initial dilution $\left(10^{-1}\right)$. Following, $1 \mathrm{~mL}$ of this initial dilution was transferred to a tube containing $9 \mathrm{~mL}$ of sterile peptone water $0.1 \%$, obtaining the dilution $10^{-2}$, and this step was repeated to obtain the dilution $10^{-3}$ (BRAZIL, 2003).

These dilutions were inoculated in duplicate on plates containing Agar-MYP and incubated on $30^{\circ} \mathrm{C}$ during $18-40$ hours. The colonies considered as suggestive of $B$. cereus group were those pink to red and lecithinase-positive (MOSSEL et al., 1967). Gram stain was performed using three to five suggestive colonies.

In order to verify if there were statistically significant differences on the counts between the different types of evaluated products, the radicalization of the counts values was carried out. When the requirements for the analysis were not a setback, the analysis was performed through non-parametric tests (Kruskal-Wallis). Data analysis was also performed through presence or absence in the products, to verify if there was a statistically significant difference. For this purpose, the products were divided into those with high and low fat (regular and light types), and with or without starch (requeijäo and especialidade láctea tipo requeijäo). Then, chi-square analysis was performed. These analyzes were carried out adopting the level of significance of $5 \%(\mathrm{p}<0.05)$.

Among the 40 lots of dairy products, 14 (35\%) showed contamination by bacteria from $B$. cereus group. REZENDELAGO et al. (2012) evaluated powdered, raw, pasteurized and ultra-high temperature processing (UHT) milks samples and isolated B. cereus in 73.3, 50.0, 96.7 and 13.3\%, respectively, demonstrating the importance of bacteria from this group in dairy products. The result of bacterial counts belonging to the $B$. cereus group is shown in Table 1 .

Although bacteria from the $B$. cereus group may be present in a wide variety of dairy products such as UHT milk, pasteurized milk, powdered milk, cheeses and fermented milks (WONG et al., 1998; REZENDE-LAGO et al., 2007), it can be observed in Table 1 that the counts of bacteria belonging to the $B$. cereus group in the evaluated dairy products were considered low. However, although low and unable to put consumers at risk, since the counts were above $10^{5} \mathrm{CFU} / \mathrm{g}-$ value required to cause foodborne diseases (FDA, 2012) the action of their spoilage enzymes can reduce the shelf life of these products (KUMARI; SARKAR, 2016).

The low occurrence of these bacteria can be explained by the fact that the milk used as raw material has a satisfactory microbiological quality, since the contamination of raw milk by spores of $B$. cereus is dependent on management in dairy farms (VISSERS et al., 2007). Also, the temperature used during curd cheeses processing is able to inactivate most of the microorganisms, with the exception of the sporulating ones. In addition to composition, $\mathrm{pH}$ and water activity (Aw), 
Table 1. Average counts of bacteria from B. cereus group on requeijão, requeijão light, especialidade láctea tipo requeijão and especialidade láctea tipo requeijão light marketed in Jaboticabal municipality, state of São Paulo, Brazil, in 2015.

\begin{tabular}{|c|c|c|c|c|c|c|c|}
\hline Product & Brand & Lot & Bacillus cereus group (CFU/g) & Product & Brand & Lot & Bacillus cereus group (CFU/g) \\
\hline \multirow{10}{*}{ Requeijão } & \multirow{2}{*}{ A } & 1 & $0.1 \times 10$ & \multirow{10}{*}{$\begin{array}{c}\text { Especialidade } \\
\text { láctea }\end{array}$} & \multirow{2}{*}{ A } & 1 & $<0.1 \times 10$ \\
\hline & & 2 & $<0.1 \times 10$ & & & 2 & $<0.1 \times 10$ \\
\hline & \multirow{2}{*}{ B } & 1 & $0.7 \times 10$ & & \multirow{2}{*}{$\mathrm{B}$} & 1 & $<0.1 \times 10$ \\
\hline & & 2 & $3.1 \times 10$ & & & 2 & $0.1 \times 10$ \\
\hline & $r$ & 1 & $<0.5 \times 10$ & & \multirow{2}{*}{ C } & 1 & $2.5 \times 10$ \\
\hline & $c$ & 2 & $<0.5 \times 10$ & & & 2 & $0.1 \times 10$ \\
\hline & \multirow{2}{*}{ D } & 1 & $<0.1 \times 10$ & & \multirow{2}{*}{ D } & 1 & $<0.1 \times 10$ \\
\hline & & 2 & $<0.1 \times 10$ & & & 2 & $<0.1 \times 10$ \\
\hline & \multirow{2}{*}{$\mathrm{E}$} & 1 & $<0.1 \times 10$ & & \multirow{2}{*}{$\mathrm{E}$} & 1 & $<0.1 \times 10$ \\
\hline & & 2 & $<0.1 \times 10$ & & & 2 & $<0.1 \times 10$ \\
\hline \multirow{10}{*}{$\begin{array}{l}\text { Requeijão } \\
\text { Light }\end{array}$} & \multirow{2}{*}{ A } & 1 & $0.4 \times 10$ & \multirow{10}{*}{$\begin{array}{c}\text { Especialidade } \\
\text { láctea light }\end{array}$} & \multirow{4}{*}{$A$} & 1 & $0.1 \times 10$ \\
\hline & & 2 & $<0.1 \times 10$ & & & 2 & $<0.1 \times 10$ \\
\hline & \multirow{2}{*}{ B } & 1 & $<0.1 \times 10$ & & & 3 & $0.7 \times 10$ \\
\hline & & 2 & $0.2 \times 10$ & & & 4 & $1.8 \times 10$ \\
\hline & \multirow{2}{*}{ C } & 1 & $<0.1 \times 10$ & & \multirow{4}{*}{ B } & 1 & $0.2 \times 10$ \\
\hline & & 2 & $<0.1 \times 10$ & & & 2 & $<0.1 \times 10$ \\
\hline & \multirow{2}{*}{ D } & 1 & $<0.1 \times 10$ & & & 3 & $<0.1 \times 10$ \\
\hline & & 2 & $<0.1 \times 10$ & & & 4 & $0.2 \times 10$ \\
\hline & \multirow{2}{*}{$E$} & 1 & $<0.1 \times 10$ & & \multirow{2}{*}{ C } & 1 & $<0.1 \times 10$ \\
\hline & & 2 & $0.1 \times 10$ & & & 2 & $<0.1 \times 10$ \\
\hline
\end{tabular}

the presence of flux salts and nisin may be inhibitory to sporulating microorganisms (JOHNSON, 2001).

Another factor that contributes to the low microbial load of these products is the bactofugation process, or Ultra-Fresh Bactofugation combines treatments that target the separation and removal of active, sporulating microorganisms and somatic cell with a subsequent heat treatment by direct injection of steam (PRATA et al., 2012). In addition, the use of preventive systems such as good manufacturing practices (GMP) and Hazard Analysis and Critical Control Points (HACCP), which are mandatory in Brazilian dairy industries, help to mitigate the risks (KUMARI; SARKAR, 2016).

The results of the $B$. cereus counts did not meet the requirements to be able to perform the analysis of variance. Then, the Kruskal-Wallis test was used. There were no statistically significant differences between the B. cereus counts ( $\mathrm{p}>0.05)$ among the different evaluated product types. The results of chi-square analysis for the presence/absence of $B$. cereus did not reveal any statistically significant difference $(p>0.05)$ between the different products. Thus, it is believed that the presence of starches or vegetable oils (requeijāo $\times$ especialidade láctea) and fat (regular $\times$ light) in the products did not significantly influence the occurrence of $B$. cereus group.
Psychrotrophic strains of $B$. cereus present greater germination and multiplication capacity in high fat dairy products due to their hydrophobic spores (LARSEN; JORGENSEN, 1997). In addition, lipids confer a protective characteristic on the spores, since fat has low-thermal conductivity (MEER et al., 1991). Consequently, the presence of lipids in food could be an important factor in the microorganism adaptation to these conditions, but no influence was observed in this study.

The counts of the B. cereus group in requeijáo and especialidade láctea tipo requeijáo were low and unable to jeopardize the consumers of these products if proper conditions of refrigeration during storage and sale are adopted. However, the present study is the first one to report the presence of such group of microorganisms in these dairy products, which requires new studies to evaluate the impact of its spoilage on the shelf life of these products routinely consumed in Brazil.

\section{ACKNOWLEDGEMENTS}

To Fundação de Amparo à Pesquisa do Estado de São Paulo (FAPESP) - grant no. 2014/21534-6. 


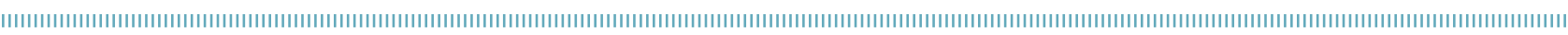
REFERENCES

BENNET, S.D.; WALSH, K.A.; GOULD, L.H. Foodborne disease outbreaks caused by Bacillus cereus, Clostridium perfringens, and Staphylococcus aureus - United States, 1998-2008. Clinical Infectious Diseases, v.57, n.3, p. 425-433, 2013.

BRAZIL. Ministério da Agricultura, Pecuária e Abastecimento. Portaria n³59, de 4 de setembro de 1997. Diário Oficial da União, Brasil, Brasília, DF, 8 set. 1997 Seção 1, p.19690-19691, 1997

BRAZIL. Instrução Normativa n 62, de 28 de Agosto de 2003. Oficializa os Métodos Analíticos Oficiais para Análises Microbiológicas para Controle de Produtos de Origem Animal e Água. Diário Oficial da União, Brasília, DF, 18 de set. 2003. Seção 1, p. 14.

FDA, Food and Drug Administration. The Bad Bug Book, Foodborne Pathogenic Microorganisms and Natural Toxins, Ed. 2, 2012. Available from: <http://www.fda.gov/downloads/Food/ FoodbornelllnessContaminants/UCM297627.pdf>. Accessed on: Dec. 052016.

GUINEBRETIÉRE, M.H.; AUGER, S.; GALLERON, N.; CONTZEN, M.; SARRAU B.; BUYSER, M.L.; LAMBERET, G.; FAGERLUND, A.; GRANUM, P.E.; LARECLUS,D.; VOS, P.; NGUYEN-THE, C.; SOROKIN, A. Bacillus cytotoxicus sp. nov. is a novel thermotolerant species of the Bacillus cereus Group occasionally associated with food poisoning. International Journal of Systematic and Evolutionary Microbiology, n.63, p.31-40, 2013.

JIMÉNEZ, G.; URDIAIN, M.; CIFUENTES, A.; LÓPEZ-LÓPEZ, A.; BLANCH, A.R.; TAMAMES, J.; KAMPFER, P.; KOLSTO, A.B.; RAMÓN, D.; MARTÍNEZ, J.F.; CODOÑER, F.M.; ROSSELLÓ-MÓRA, R. Description of Bacillus toyonensis sp. nov., a novel species of the Bacillus cereus group, and pairwise genome comparisons of the species of the group by means of ANI calculations. Systematic and Applied Microbiology, v.36, n.6, p.383-391, 2013. Available from: <http://dx.doi.org/10.1016/j.syapm.2013.04.008>. Accessed on: Dec. 052016.

JOHNSON, M.E. Cheese Products. In: MARTH, E.H.; STEELE, J.L. Applied Dairy Microbiology. Nova lorque: Marcel Dekker. Cap. 11. 2001

KOVAC, J.; MILLER, R.A.; CARROLL, L.M.; KENT, D.J.; JIAN J.; BENO, S.M.; WIEDMANN, M. Production of hemolysin BL by Bacillus cereus group isolates of dairy origin is associated with whole-genome phylogenetic clade. BMC Genomics, v. 17, n.581, 2016. Available from: Doi: 10.1 186/s1 2864-016-2883-z. Accessed on: Dec. 052016.
KUMARI, S.; SARKAR, P. Bacillus cereus hazard and control in industrial dairy processing environment. Food Control, v.69, p.20-29, 2016.

LARSEN, H.D.; JORGENSEN, K. The occurrence of Bacillus cereus in Danish pasteurized milk. International Journal of Food Microbiology, v.34. p.179-186, 1997.

MEER, R.R.; BAKER, J.; BODYFELT F.W.; GRIFFITHS, M.W. Psychrotrophic Bacillus spp. in fluid milk products: a review. Journal of Food Protection, v.54, n. 12, p.969-979, 1991.

MOSSEL, D.A.A.; KOOPMAN, M.J.; JONGERIUS, E. Enumeration of Bacillus cereus in foods. Applied Microbiology, v.15, n.3, p.650-653, 1967.

PRATA, L.F.; OLIVEIRA, C.F.; PRATA, A.B.; MACHADO, R.C. Qualidade do leite cru antes e após o processo Ultrafresh. Indústria de Laticínios, v.96, p.58-65, 2012.

REZENDE-LAGO, N.C.M.; ROSSI JUNIOR, O.D.; VIDAL-MARTINS, A.M.C.; AMARAL, L.A. Occurrence of Bacillus cereus in whole milk and enterotoxigenic potential of the isolated strains. Arquivo Brasileiro de Medicina Veterinária e Zootecnia, v.59, n.6, p.15631569, 2007.

VISSERS, M.M.M.; TE GIFFEL, M.C.; DRIEHUIS, F.; DE JONG, P.; LANKVELD, J.M.G. Predictive modeling of Bacillus cereus spores in farm tank milk during grazing and housing periods. Journal of Dairy Science, v.90, n. 1, p.281-292, 2007.

ZACARCHENCO, P.B.; VAN DENDER, A.G.F.; SPADOTI, L.M. "Requeijão" culinário: Aspectos históricos, de mercado e tecnológicos. Revista das Indústrias de Laticínios - São Paulo, v. 18, p.70-74, 2012.

ZHOU, G.; BESTER, K.; LIAO, B.; YANG, Z.; JIANG, R.; HENDRIKSEN, N.B. Characterization of three Bacillus cereus strains involved in a major outbreak of food poisoning after consumption of fermented black beans (douchi) in Yunan, China. Foodborne Pathogens (2) Diseases, v.11, n.10, p.769-774, 2014.

WONG, H.C.;CHANG, M.H.; FAN, J.Y. Incidence and characterization of Bacillus cereus isolates contaminating dairy products. Applied Environmental Microbiology, v.54, n.3, p.699-702, 1988. 